\title{
Process Solutions for Recovery of Dimethyl Ether Produced Through One-Step Synthesis and Their Assessment
}

\author{
M. I. Afokin ${ }^{a, *}$ and M. V. Magomedova ${ }^{a}$ \\ ${ }^{a}$ Topchiev Institute of Petrochemical Synthesis, Russian Academy of Sciences, Moscow, 119991 Russia \\ *e-mail: m_afokin@ips.ac.ru
}

Received September 14, 2020; revised October 15, 2020; accepted November 15, 2020

\begin{abstract}
A number of process solutions for one-step synthesis of dimethyl ether (DME), including a step of its recovery from the gaseous and liquid phases, were reviewed. It was demonstrated that energy-intensive absorption is the most common method for DME recovery from a gaseous stream containing syngas components. It was also shown that the world licensors of one-step DME synthesis provide for an additional dehydration reactor to utilize the methanol co-product. Energy and capital intensity was estimated for two DME production options, specifically the methanol dehydration route and the one-step DME synthesis over a bifunctional catalyst. Finally, it was demonstrated that the one-step option is inferior to the two-step design in terms of both criteria, and that the key cost factor is associated with DME recovery from the gaseous phase.
\end{abstract}

Keywords: dimethyl ether, one-step DME synthesis, two-step DME synthesis, energy assessment

DOI: $10.1134 / \mathrm{S} 0965544121020109$

Over the last two decades, researchers have paid much attention to dimethyl ether, which is a clean fuel and, at the same time, a large-capacity intermediate product in petrochemical processing of natural gas into various hydrocarbons (e.g., lower olefins, $\mathrm{C}_{5}-\mathrm{C}_{11}$ liquid hydrocarbons, aromatic hydrocarbons, and oxymethylated ethers) [1-3] and hydrogen [4].

An industrial-scale DME production process consists of two steps. Methanol is first obtained at 5.0 to $10.0 \mathrm{MPa}$ in a reactor equipped to recycle unreacted syngas. The methanol is then concentrated in two or three distillation columns where ethers, esters, acetone, dissolved noncondensable gases, water, and higher alcohols are recovered. The methanol stream is heated and directed to a dehydration reactor to produce DME. DME is synthesized at 0.3 to $2.0 \mathrm{MPa}$ in a single-stage (or, less often, doublestage) adiabatic apparatus with a fixed catalyst bed. Because the equilibrium methanol conversion does not exceed $80 \%$, the process design generally provides for the recycling of unreacted methanol from the separation step to the DME synthesis reactor inlet. The methanol/ water/DME mixture is separated in a series of two distillation columns. Two-step DME technologies have been licensed by Johnson Matthey [5], Lurgi, Haldor Topse [6], and Mitsubishi Gas Chemical [7, 8]. The main drawback of the two-step DME process design is the high energy consumption required for cooling the contact gas to extract methanol and the subsequent heating of the methanol stream prior to entering the DME reactor.

From this point of view, a one-step syngas-to-DME production method, which allows for DME to be obtained over a bifunctional catalyst without interposed cooling and heating steps, is assumed to be the preferable solution. The equipment implementation of the DME reactor system is similar to that of the methanol reactor system. The 5.0-10.0 MPa syngas is heated to $240-260^{\circ} \mathrm{C}$ and delivered to the DME synthesis reactor. The contact gas exiting the reactor is cooled, with its portion being condensed and sent to a two-phase separator. The reaction is carried out under gas circulation conditions to enhance the feedstock conversion rate. For this purpose, a major gas portion is recirculated and a lesser portion is purged. Various reactor types, such as adiabatic multistage reactors, shell-and-tube reactors, and slurry reactors, have been suggested for DME production [9-11].

A bifunctional catalyst promotes formation of methanol along with DME. In addition, one-step DME synthesis gives rise to a by-product, specifically water or $\mathrm{CO}_{2}$ depending on the $\mathrm{H}_{2} / \mathrm{CO}$ ratio in the initial syngas. During the fluid separation in the separator, DME, as well 
Table 1. Binary interaction coefficients between flow components and DME

\begin{tabular}{c|c|c|c|c|c}
\hline \multirow{2}{*}{ Components } & \multicolumn{5}{|c}{ DME } \\
\cline { 2 - 6 } & $\mathrm{N}_{2}$ & $\mathrm{CO}$ & $\mathrm{H}_{2}$ & $\mathrm{CO}_{2}$ & $\mathrm{H}_{2} \mathrm{O}$ \\
\hline$K_{i j}^{\mathrm{A}}$ & 0.16455 & -0.18011 & -1.24929 & -0.01308 & -0.27388 \\
\hline
\end{tabular}

as $\mathrm{CO}_{2}$, dissolves sufficiently well in the water-methanol condensate due to DME's physicochemical properties under high pressure conditions, while some portion of it is drawn off with the gaseous phase. The ratio between the DME contained in the gaseous phase and the DME in the water condensate, at 2.0 to $10.0 \mathrm{MPa}$ and $20^{\circ} \mathrm{C}$, varies from $75: 1$ to $20: 1$ (by weight). Therefore, DME recovery from the gaseous phase presents a relevant problem.

This paper discusses a number of process solutions suggested for DME recovery from the gaseous phase, and provides an assessment of capital and energy intensity using a one-step DME synthesis/recovery design developed by the Topchiev Institute of Petrochemical Synthesis of the Russian Academy of Sciences (TIPS RAS) as an example.

\section{COST ESTIMATIONS}

The capital expenditures (CAPEX) and operating expenditures (OPEX) of syngas-to-DME production were estimated for two design options.

Option 1, a two-step DME production arrangement, includes methanol production and its dehydration with separation of a methanol/DME/water mixture in two distillation columns.

(a)

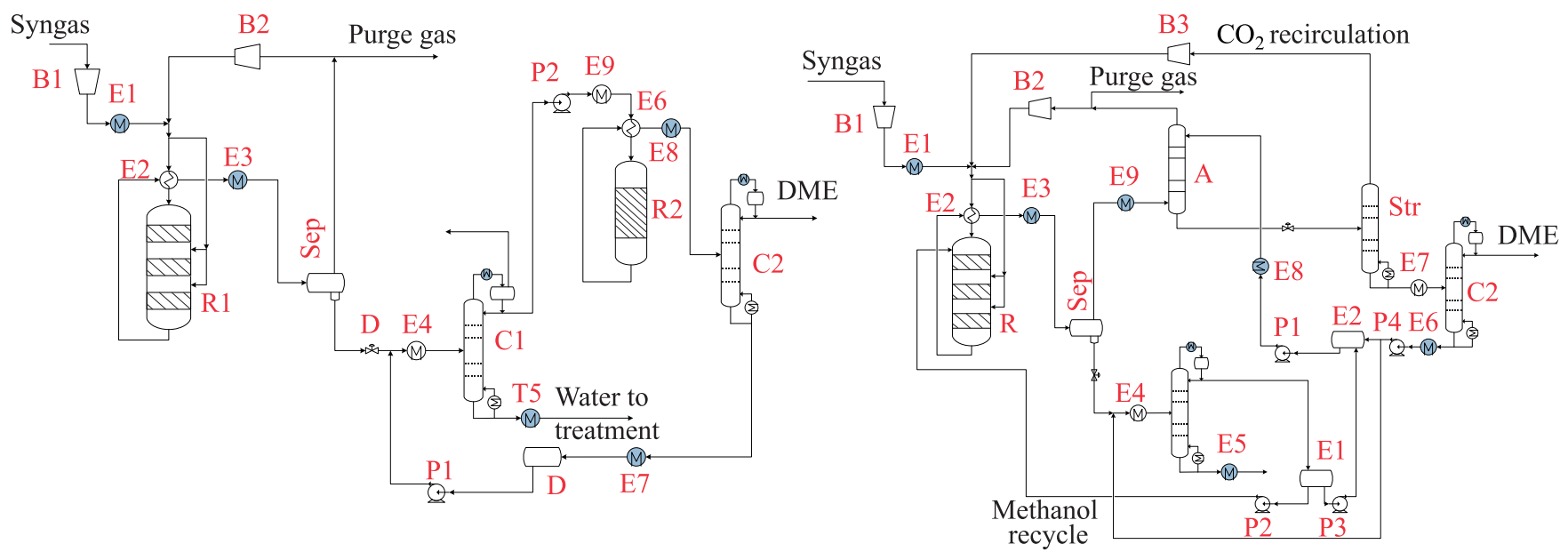

Fig. 1. Syngas-to-DME production options: (a) two-step DME process (B1, B2 = Compressors; E1-E9 = Heat exchangers; $\mathrm{R} 1$ = Methanol reactor; R2 = DME reactor; Sep = Separator; Thr = Throttle; C1, C2 = Distillation columns; P1, P2 = Pumps; D = Intermediate drum) and (b) one-step DME process (B1-B3 = Compressors; E1-E8 = Heat exchangers; R = One-step DME reactor; Sep = Separator; C1, C2 = Distillation columns; A = Absorber; Str = Stripper; P1-P4 = Pumps; D1, D2 = Intermediate drums) [12].
Option 2, a one-step DME production arrangement using a bifunctional catalyst, provides for DME separation from the gaseous stream according to a patented flowchart [12]. Option 2, along with the separation of the methanol/water and methanol/DME mixtures in the distillation columns, includes the methanol absorption of the gaseous stream and a $\mathrm{CO}_{2}$ stripper. The material and thermal balances of both process options and the equipment dimensions were computed in Aspen Plus. The corresponding process flowcharts are provided in Fig. 1.

The steam reforming syngas of the following composition was used in the computation as a feedstock (vol \%): $\mathrm{H}_{2} 74.3 ; \mathrm{CO} 15.5 ; \mathrm{CO}_{2} 6.9 ; \mathrm{CH}_{4}$ 3.3. Fresh syngas flow rate was assumed to be $575 \mathrm{kmol} / \mathrm{h}$, which corresponds to a natural gas capacity of 25 million $\mathrm{Nm}^{3} /$ year, one-step DME reactor (or the methanol reactor, as the case may be) of 5. The one-step DME reactor and the methanol reactor were assumed to be implemented as a three-stage adiabatic apparatus with interstage contact gas cooling by the syngas stream as a cold quench. The single-stage adiabatic methanol dehydration reactor was computed at pressure of $1.0 \mathrm{MPa}$ and a $\gamma-\mathrm{Al}_{2} \mathrm{O}_{3}$ bed inlet temperature of $300^{\circ} \mathrm{C}$. pressure of $5.0 \mathrm{MPa}$, and a recirculation ratio in the (b)

PETROLEUM CHEMISTRY Vol. 61 No. 22021 


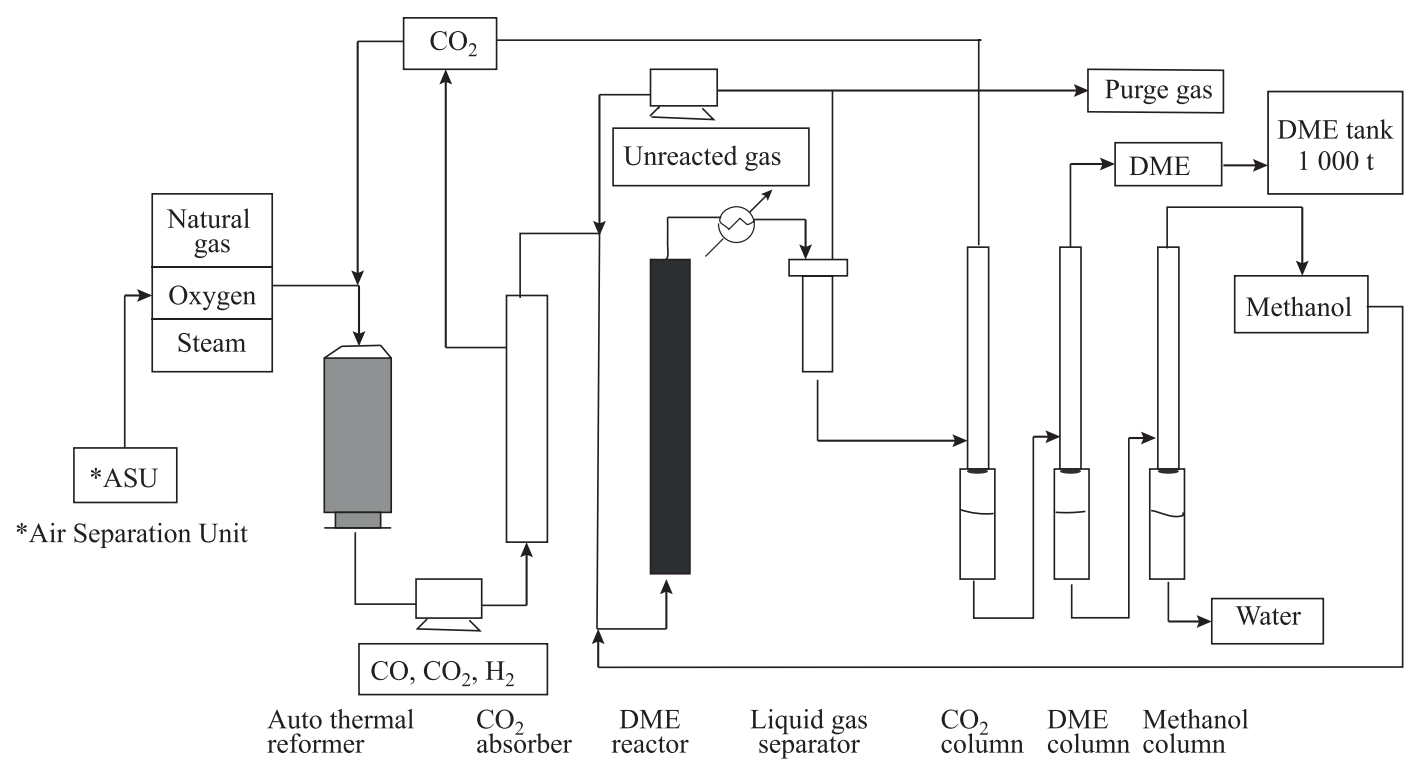

Fig. 2. JFE one-step DME synthesis process [22].

The catalyst loading and material balance of the reactors in both options were calculated using kinetic models developed by the TIPS RAS Kinetics Laboratory under the supervision of G.I. Lin and M.A. Kipnis [13-15].

The thermodynamic properties of the system components were simulated using a Penga-Robinson method widely applicable for such systems [16]. The two-phase separator was designed for $40^{\circ} \mathrm{C}$ and 5.0 MPa. The binary interaction coefficients between the flow components and $\operatorname{DME}\left(K_{i j}^{\mathrm{A}}\right)$, which are unavailable from the standard Aspen Plus database, are presented in Table 1.

The cost of the major equipment for construction of a process facility of specified production capacity was estimated in accordance with the method described in [17], taking into account the 2018 Chemical Engineering Plant Cost Index (CEPCI) of 603.1 [18] and the US Gulf Coast/RF equipment cost conversion factor of 2.5. The major equipment cost includes expenditures for equipment surroundings (piping, foundations, instrumentation, electricals, and insulation), construction and installation works, and indirect costs (e.g., insurance, taxes, payments to the general contractor, and contingencies). The total investments were estimated based on the cost breakdown for similar petrochemical projects [19]. Taking the net equipment value as a reference base $(100 \%)$, the costs of construction of industrial and office facilities were assumed as $120 \%$, the engineering supervision cost as $50 \%$, and the working capital cost as $80 \%$.

\section{RESULTS AND DISCUSSION}

DME recovery technologies. The technologies for DME recovery from the liquid/gaseous phase cannot be considered independently of the respective one-step DME production process. In this connection, the main features of existing direct DME synthesis technologies are discussed and compared below for better understanding of the general picture. The world technology licensors are JFE (Japan Future Enterprise, Japan), KOGAS (Korea), Air Products \& Chemicals (the U.S.), and Haldor Topsoe (Denmark). Their proposed process solutions have been tested on a pilot and demo scale, but have not yet been implemented on an industrial scale.

The JFE technology uses a syngas $\left(\mathrm{H}_{2} / \mathrm{CO}=1\right)$ obtained by auto-thermal reforming followed by $\mathrm{CO}_{2}$ recovery and recycle to the reformer (the so-called "tri-reforming") [20]. DME synthesis is carried out at $5.0 \mathrm{MPa}$ in a three-phase reactor using mineral oil as a dispersion medium [21]. The reactor operates under flowcirculation conditions, where the cooling, condensation, and separation of the contact gas in a two-phase separator is followed by recycling of the gaseous phase to the DME reactor inlet. The liquid phase from the separator is separated in a series of three columns: a stripper (a column without a concentrating section) for $\mathrm{CO}_{2}$ recovery and two distillation columns for the methanol-DME-water mixture separation. This process design is distinguished by the recycle of the $\mathrm{CO}_{2}$ recovered in the stripper to the auto-thermal reforming step, as well as the recycle of methanol to the DME synthesis reactor (Fig. 2). The 
Table 2. Performance characteristics of one-step DME synthesis technologies

\begin{tabular}{l|c|c|c|c}
\hline \multicolumn{1}{c|}{ Licensor } & JFE & KOGAS & Air products & Haldor topse \\
\hline $\mathrm{H}_{2} / \mathrm{CO}$ & 1.0 & 1.0 & 0.7 & 2.0 \\
Reactor, catalyst bed & Slurry & Fixed & Slurry & Fixed \\
$T,{ }^{\circ} \mathrm{C}$ & $250-280$ & $230-280$ & $250-280$ & $210-290$ \\
$P, \mathrm{MPa}$ & 5 & 6 & $5-10$ & $7-8$ \\
CO conversion per pass, \% & 50 & 65 & 33 & 18 \\
Total CO conversion, \% & 96 & 82 & $89-93$ & \\
DME, mol \% & 93 & 67 & $30-80$ & $60-70$ \\
\hline
\end{tabular}

process was tested in 2003-2006 at a 100 ton/day demoplant (Shiranuka-cho, Hokkaido, Japan) [21].

The JFE technology makes it possible to produce DME with $99.6 \mathrm{wt} \%$ purity [23]. However, the technology has some drawbacks, including a difficulty of hydrodynamic upscaling in a three-phase reactor and the overly large dimensions of the DME reactor when a higher reactor capacity is required. For example, a 100 ton/day (33.5 kt/year) reactor will necessarily be $2.3 \mathrm{~m}$ in height and $22 \mathrm{~m}$ in diameter. A capacity increase to 3000 ton/day $(1000 \mathrm{kt} /$ year $)$ would require a $50 \mathrm{~m}$ high $\times 7.0 \mathrm{~m}$ dia. reactor [24].

Another process solution has been suggested by KOGAS (Fig. 3). While applying tri-reforming for syngas production, similar to the JFE technology, this process uses an original design for a reactant mixer [25]. The Rectisol [26] or Selexol [27] technology is employed for $\mathrm{CO}_{2}$ recovery from syngas. A water-cooled shell-andtube reactor is used for DME synthesis at 6.0 MPa [28]. After cooling and condensation of the contact gas, the liquid phase leaving the reactor is reduced to $3.5 \mathrm{MPa}$. This results in the desorption of $\mathrm{CO}_{2}$, the major portion of which is also recycled to the reformer. The methanol co-product is sent to a dehydration reactor to produce an additional amount of DME and is used as a makeup absorbent to remove $\mathrm{CO}_{2}$ from the syngas under the Rectisol technology [29, 30].

The KOGAS technology makes it possible to produce DME with 99.6 wt \% purity. The KOGAS 10 ton DME/day demo-plant launched in 2008 ran for 78 days [32].

Thus, the KOGAS process solution is aimed at recovery and disposal of $\mathrm{CO}_{2}$, which is achieved through utilization of three columns (one absorber, one desorber, and one $\mathrm{CO}_{2}$ stripper). DME is only recovered from the liquid phase by distillation.

Air Products \& Chemicals have proposed a threephase reactor with built-in heat exchangers to produce DME from syngas [33]. This process design has the following features: the liquid phase from a two-phase separator is delivered to a one-step DME synthesis

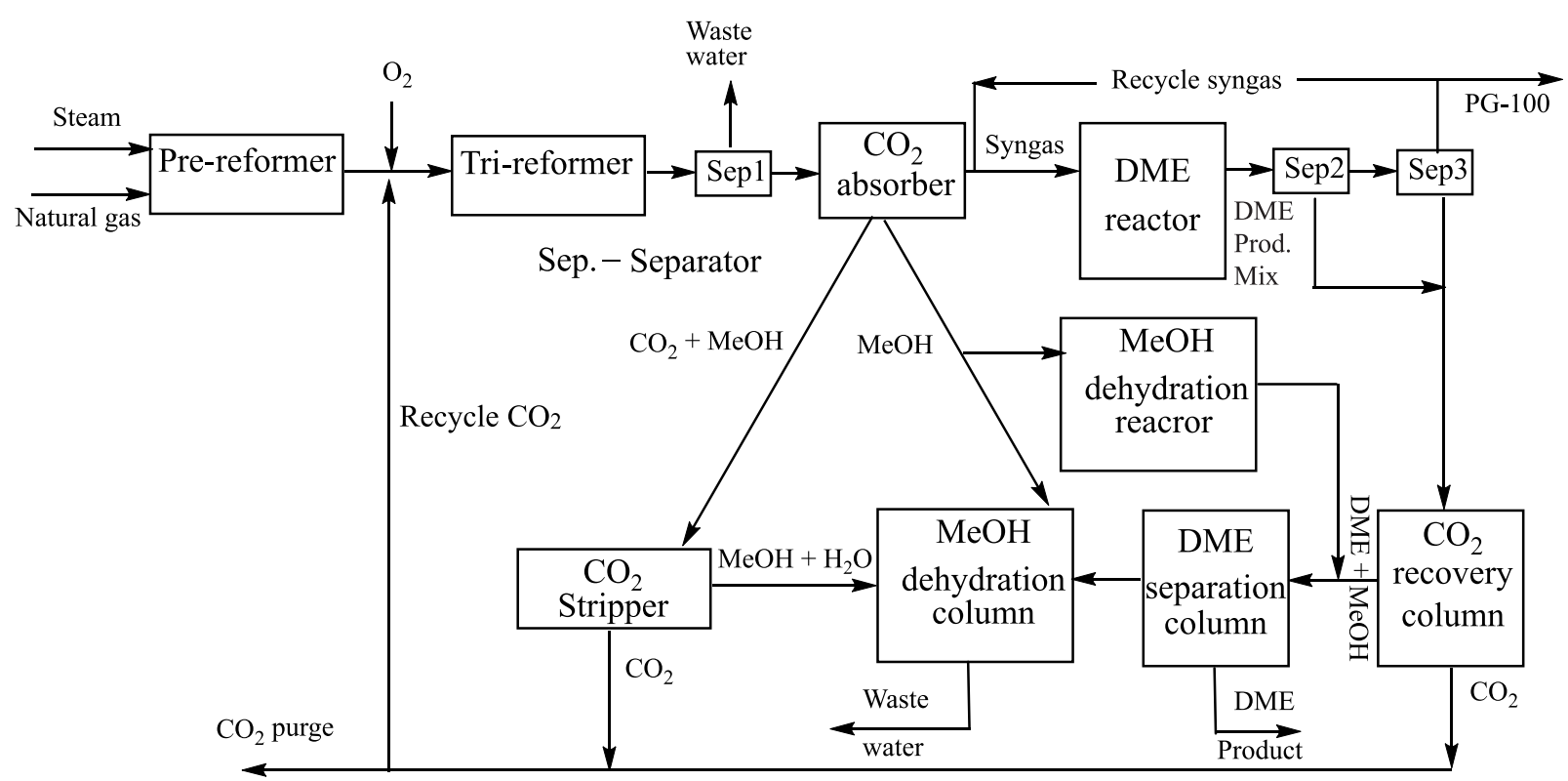

Fig. 3. KOGAS one-step DME synthesis process [31]. 
Table 3. Raw material and utility consumption ratios

\begin{tabular}{l|l|c|c}
\hline \multicolumn{1}{c|}{ Parameter } & Unit & Option 1 two-step & Option 2 one-step \\
\hline DME capacity & $\mathrm{kt} / \mathrm{year}$ & 24.8 & 21.6 \\
Natural gas & $\mathrm{m}^{3} / \mathrm{t} \mathrm{DME}$ & 1050 & 1180 \\
Fuel gas (reforming) & $\mathrm{m}^{3} / \mathrm{t} \mathrm{DME}$ & 520 & 590 \\
Syngas & $\mathrm{m}^{3} / \mathrm{t} \mathrm{DME}$ & 4207 & 4725 \\
Electric power & $\mathrm{kW} / \mathrm{t} \mathrm{DME}$ & 274 & 342 \\
Steam $(P=4.0 \mathrm{MPa})$ & $\mathrm{Gcal} / \mathrm{t} \mathrm{DME}$ & 1.86 & 3.65 \\
Cooling water & $\mathrm{m}^{3} / \mathrm{t} \mathrm{DME}$ & 67 & 109 \\
\hline
\end{tabular}

reactor; DME is recovered from the gaseous phase by methanol absorption; and a methanol dehydration reactor is used to produce an additional DME [10]. As described in the referenced paper, the process design is rather flexible in terms of flow directions. However, the technology's major disadvantage is the high metal content of the reactor: a 5 ton DME/day plant requires a $0.46 \mathrm{~m}$ dia. $\times 15 \mathrm{~m}$ high reactor.

Haldor Topsoe has proposed its own one-step technology for synthesis of DME fuel (89 wt \% DME), which involves a three-stage adiabatic apparatus with interstage contact gas cooling or a series of a shell-and-tube methanol reactor and an adiabatic one-step DME reactor $[34,35]$. Unreacted syngas is recycled to the process. For an option of syngas feedstock with $\mathrm{H}_{2} / \mathrm{CO} \geq 2$, the product separation design includes a two-phase separator, methanol absorption of DME from the gaseous phase, dehydration of the saturated absorbent, and separation of the methanol-DME-water mixture by distillation [36]. In the case of $\mathrm{H}_{2} / \mathrm{CO}$ ratio of about 1 , the process design provides for removal of $\mathrm{CO}_{2}$ from the circulating syngas through absorption (using monoethanol amine or dialkyl ether of polyalkylene glycol) and zeolite adsorption [37,38].

The option of DME and $\mathrm{CO}_{2}$ recovery from the circulating syngas stream by absorption has also been discussed in patents of Gastec NV (Netherlands) [39], Leuna-Werke AG (Germany) [40], Nippon Kokan Corporation (Japan) [41], Boreskov Institute of Catalysis SB RAS (Russia) [42], and UOP [43].

The main performance characteristics of the above mentioned process technologies are compared in Table 2.

In addition to absorption methods for DME condensation, methods for deep chilling of the contact gas leaving the DME synthesis reactor with the use of lowtemperature refrigerants, such as ammonia, DME, or ethylene-propylene mixture, are suggested [44-46]. However, it should be understood that implementation of this approach involves extra energy consumption and, moreover, requires an appropriate infrastructure to be provided at the petrochemical plant.

Thus, the review of one-step DME technologies clearly shows that the DME recovery from the liquid phase, i.e., from a methanol-DME-water mixture, requires a series of two distillation columns to be installed. DME recovery from the gaseous phase is implemented by absorption where methanol, a co-product from one-step DME synthesis, is used as an absorbent. In addition, $\mathrm{CO}_{2}$ is recovered by absorption from the circulating syngas and is sent to the syngas production step to enhance the carbon utilization. Moreover, nearly all of the proposed process designs involve a methanol dehydration step to produce an additional amount of DME.

Comparative assessment of CAPEX and OPEX for DME production by different methods. A number of studies have discussed simulation of one-step DME synthesis in Aspen Plus [45, 47-49]. However, these generally do not consider DME recovery from the gaseous phase but, instead, are aimed at development of $\mathrm{CO}_{2}$ disposal methods.

This paper reports the Aspen Plus computation and comparative assessment of energy consumption and capital investment, given the Russian conditions, for two DME process options: the methanol dehydration route (Option 1) and the one-step DME synthesis (Option 2). For $575 \mathrm{kmol} / \mathrm{h}$ of fresh syngas, other conditions being equal $(P=5.0 \mathrm{MPa}$, recirculation ratio $=5)$, the $97 \mathrm{wt} \%$ DME product capacity will amount to $3.1 \mathrm{t} / \mathrm{h}$ in Option 1 and $2.7 \mathrm{t} / \mathrm{h}$ in Option 2.

The consumption of raw materials and utilities (electric power, steam, cooling water) per ton of DME product in both options is presented in Table 3 .

Option 2 has distinctly higher steam and power consumptions due to the need to regenerate a large amount of methanol absorbent, with subsequent recovery of $\mathrm{CO}_{2}$ from the absorbent in the DME recovery column and recycle of the $\mathrm{CO}_{2}$ to the DME synthesis reactor. For this purpose, an additional compressor is installed (to 
Table 4. Quantity and cost of equipment

\begin{tabular}{l|c|c|c|c}
\hline \multirow{2}{*}{ Type of major process equipment } & \multicolumn{2}{|c|}{ Option 1 two-step } & \multicolumn{2}{c}{ Option 2 one-step } \\
\cline { 2 - 5 } & quantity & price, thousand US\$ & quantity & price, thousand US\$ \\
\hline Reactor & 2 & 1212.5 & 1 & 1517.5 \\
Column & 2 & 703.3 & 4 & 3002.0 \\
Heat exchanger, including & 13 & 3224.2 & 12 & 3395.5 \\
Reboiler & 2 & - & 3 & - \\
Condenser & 2 & - & 2 & - \\
Steam heater & 2 & - & 2 & - \\
Interchanger & 2 & - & 1 & - \\
Cooler & 5 & - & 4 & - \\
Compressor & 2 & 3714.0 & 3 & 116.0 \\
Pump & 3 & 78.0 & 4 & 2380.0 \\
Vessel & 3 & 9683.0 & 4 & 14703.0 \\
Total & 38 & & 40 &
\end{tabular}

pressurize from 1.0 MPa at the stripper outlet to $5.0 \mathrm{MPa}$ at DME synthesis).

The comparative assessment of CAPEX for construction of a DME synthesis system of specified capacity, including piping, instrumentation, insulation, painting, concrete foundation, and steel structures, is summarized in Table 4.

Despite the substantially equal quantity of equipment, Option 2 has a higher metal content due to the required absorptive separation of DME and $\mathrm{CO}_{2}$ in the gaseous phase.

The Total Capital Investment (TCI) for implementation of either option was estimated based on the cost breakdown. Taking into account the construction of industrial and office facilities, engineering supervision, and working capital for plant operation, the total costs amount to US\$10.93 million for Option 1 and US\$16.6 million for Option 2. The specific TCI for Option 1 (twostep DME process) can be estimated as about US $\$ 440.8 / \mathrm{t}$ DME, which is 1.7 times lower than US\$768.5/t DME for one-step Option 2.

Given the natural gas price of $4 \mathrm{RUB} / \mathrm{m}^{3}$, and taking into account the raw material and auxiliary material consumption ratios depending on the internal value of utilities, the DME manufacturing cost can be estimated as US\$350-375/t DME for Option 1 and US\$430-455/t DME for Option 2, which corroborates prior reports [45].

The high DME manufacturing cost in the one-step case is primarily associated with the expenditures on extra column and vessel equipment for DME recovery from the syngas stream, despite the energy benefits gained by the elimination of the cooling and heating steps between the reactors. This provides good opportunities for implementation of a one-step DME synthesis design in combination with technologies to be developed for direct DME conversion into valuable petrochemicals without the step of DME concentration from the gaseous stream [50-53].

\section{CONCLUSIONS}

The energy consumption and capital intensity were estimated for two options of DME process design, the one involving a methanol synthesis step and the other consisting of one process step over a bifunctional catalyst. It was demonstrated that the one-step option is inferior in terms of both criteria, and that the key cost factor of the one-step route implementation is the complexity of DME recovery from the gaseous phase.

Thus, it can be concluded that a one-step DME synthesis technology is effective only provided that DME is subsequently processed into valuable petrochemicals (e.g., olefins, $\mathrm{C}_{5+}$ hydrocarbons, oxymethylated ethers, etc.) without the need to concentrate it from the gaseous phase.

\section{AUTHOR INFORMATION}

M.I. Afokin, ORCID: http://orcid.org/0000-0001-71822229

\section{FUNDING}

The study described here was performed within the framework of the state assignment for the TIPS RAS.

\section{CONFLICT OF INTEREST}

The authors declare no conflict of interest requiring disclosure in this article.

PETROLEUM CHEMISTRY Vol. 61 No. 22021 


\section{OPEN ACCESS}

This article is distributed under the terms of the Creative Commons Attribution 4.0 International License (http:// creativecommons.org/licenses/by/4.0/), which permits unrestricted use, distribution, and reproduction in any medium, provided you give appropriate credit to the original author(s) and the source, provide a link to the Creative Commons license, and indicate if changes were made.

\section{REFERENCES}

1. Magomedova, M.V., Peresypkina, E.G., Davydov, I.A., and Khadzhiev, S.N, Petrol. Chem., 2017, vol. 57, p. 1043. https://doi.org/10.1134/S0965544117100115

2. Magomedova, M.V., Peresypkina, E.G., Ionin, D.A., Afokin, M.I., Golubev, K.B., and Khadzhiev, S.N., Petrol. Chem., 2017, vol. 57p. 674 https://doi.org/10.1134/S0965544117120076

3. Haltenort, P., Hackbarth, K., Oestreich, D., Lautenschütz, L., and Arnold, U., Catal. Commun., 2018, vol. 109, p. 80 .

https://doi.org/10.1016/j.catcom.2018.02.013

4. Park, S., Kim, H., and Choi, B., J. Ind. Eng. Chem., 2010, vol. 16 , no. 5, p. 734 .

https://doi.org/10.1016/j.jiec.2010.07.010

5. https://matthey.com/en/products-and-services/chemicalprocesses/licensed-processes/dimethyl-ether-process.

6. https://www.topsoe.com/ru/tehnologii/dimetilovyy-efir.

7. https://www.mgc.co.jp/eng/products/nc/dimethyl-ether. html.

8. https://www.mhi.com/products/energy/dimethyl_ether_ plant.html.

9. Yotaro,O.,Masahiro, Y.,Tsutomu,S.,Osamu,I., Takashi,O., and Norio, I., JFE Tech. Report, 2006, no. 8, p. 34.

10. Peng, X., Diamond, B.W., Tsao, T.R., and Bhatt, B.L., US Patent 6458856 B1, 2002

11. Azizi, Z., Rezaeimanesh, M., Tohidian, T., and Rahimpour, M.R., Chem. Eng. Proc., 2014, vol. 82, p. 150. https://doi.org/10.1016/j.cep.2014.06.007

12. Khadzhiev, S.N. and Magomedova, M.V., RF Patent 2528409, 2013.

13. Polikarov, I.V., Candidate Sci. (Chem.) Dissertation, Moscow, 2003.

14. Matyshak, V.A., Sadykov, V.A., Sil'chenkova, O.N., Lin, G.I., and Rozovskii, A.Ya., Kinet. Catal., 2020, vol. 61, no. 1, p. 126. https://doi.org/10.1134/S0023158420010061

15. Magomedova, M.V., Starozhickaya, A.V., Afokin, M.I., Perov, I.V., Kipnis, M.A., and Lin, G.I., Neftekhim. In press

PETROLEUM CHEMISTRY Vol. 61 No. 22021
16. Peng, D.Y. and Robinson, D.B., Ind. Eng. Chem. Fundament., 1976, vol. 15, no. 1, p. 59. https://doi.org/10.1021/i160057a011

17. Seider, W.D., Seader, J.D., and Lewin, D.R., Product \& Process Design Principles, 2nd ed., John Wiley \& Sons, 2004.

18. Piazzi, S., Zhang, X., Patuzzi, F., and Baratieri, M., Waste Management, 2020, vol. 105, p. 550. https://doi.org/10.1016/j.wasman.2020.02.038

19. Xiang, D., Yang, S., Mai, Z., and Qian, Y., Comput. Chem. Eng., 2015, vol. 83, no. 5, p. 176 https://doi.org/10.1016/j.compchemeng.2015.03.007

20. Ohno, Y., DeWitt Asia Pacific Global Methanol \& MTBE Conference, Ho Chi Minh City, Vietnam, 3-5 March, 2008.

21. Ogawa, T., Inoue, N., Shikada, T., and Ohno, Y., J. Natur. Gas Chem., 2003, vol. 12, no. 4, p. 219.

22. Ohno, Y., Yoshida, M., Shikada, T., Inokoshi, O., Ogawa, T., and Inoue, N., JFE Tech. Report., 2006, no. 8, p. 34.

23. Ogawa, T., Inoue, N., Shikada, T., Inokoshi, O., and Ohno, Y., Stud. Surface Sci. Catal., 2004, vol. 147, p. 379 .

https://doi.org/10.1016/S0167-2991(04)80081-8

24. Ohno, Y., Yagi, H., Inoue, N., Okuyama, K., and Aoki, S., Int. J. Chem. React. Eng., 2010, vol. 8, no. 1, p. A109. https://doi.org/10.2202/1542-6580.2267

25. Cho, W., Song, T., Mitsos A. McKinnon, J.T., Ko, G.H.,Tolsma, J.E., Denholm, D., and Park, T., Catal. Today., 2009, vol. 139/, no. 4, p. 261. https://doi.org/10.1016/j.cattod.2008.04.051

26. https://www.engineering-airliquide.com/ru/rectisoltmochistka-sintez-gaza.

27. https://www.clariant.com/ru-RU/Business-Units/Industrial-and-Consumer-Specialties/Gas-Treatment.

28. Song, D., Cho, W., Lee, G., Park, D.K., and Yoon, E.S., Ind. Eng. Chem. Res., 2008, vol. 47, p. 4553. https://doi.org/10.1021/ie071589e

29. Cho, W., Mo, Y., Song, T., Lee, H., Baek, Y., Denholm, D., Ko, G., and Choi, Ch., Trans. Korean Hydrogen and New Energy Soc., 2011, vol. 22, no. 6, p. 925. https://doi.org/10.7316/khnes.2011.22.6.925

30. Yang, Sh., Qian, Y., and Yang, S., Ind. Eng. Chem. Res., 2016, vol. 55, no. 21, p. 6186. https://doi.org/10.1021/acs.iecr.6b00747

31. Kim, I.H., Kang, B.J., and Yoon, E.S., Proceedings of the 11th International Symposium on Process Systems Engineering, 15-19 July, 2012, Singapore.

32. Cho, W., 7th Asian DME Conference, November, 16, 2011. 
33. Air Products and Chemicals, Inc. and Eastman Chemical Company. Topical Report. Liquid Phase Dimethyl Ether Demonstration in the LaPorte Alternative Fuels Development Unit., 2001.

34. Dybkjaer, I. and Hansen, J.B., Natur. Gas Convers. IV Studies in Surface Sci. Catal., 1997, vol. 107, p. 99. https://doi.org/10.1016/S0167-2991(97)80322-9

35. Jones, G.R., Holm-Larsen, H., Romani, D., and Sills, R.A., Petrotech-2001, New Delhi, India, 2001.

36. Voss, B., Joensen, F., and Hansen, J.B., US Patent 5908963, 1999.

37. Madsen, Y., RF Patent 2469017, 2010.

38. Rostrup-Nil'sen, T. and Madsen, J., RF Patent $2008149042,2010$.

39. Siebrand, T.A., Vvan der Ham Aloysius, G., and Van Hessem Marco, R., WO Patent 9921814, 1997.

40. Becker, K., HolmR., KohlG., Schmidt, G., and Timm, D., DE Patent 4222655, 1994.

41. Fujimoto, K., Mizuguchi, M., Ogawa, T., Ohno, Y., Ono, M., and Shikada, T., US Patent 6147125, 2000.

42. Mysov, V.M., Ione, K.G., and Parmon, V.N., RF Patent 2143417, 1998.

43. Bodzano, A., RF Patent 2011103176, 2012.

44. Kortbeek, A.G.T. and Scheffer, B., GB Patent 2253623, 1992.
45. Mevawala, Ch., Jiang, Y., and Bhattacharyya, D., Appl. Energ., 2017, vol. 204, p. 163. https://doi.org/10.1016/j.apenergy.2017.06.085

46. Rozovskii, A.Ya., Lin, G.I., Kotel'nikov, V.N., Maidurov, N.P., Petrov, V.N., Brand, B.B., and Makhlin, V.A. RF Patent 2220939, 2002.

47. Zhang, Y., Zhang, S., and Benson, T., Fuel Proc. Technol., 2015, vol. 131, p. 7. https://doi.org/10.1016/j.fuproc.2014.11.006

48. Parvez, A.M., Mujtaba, I.M., Hall, P., Lester, E.H., and Wu, T., Energ. Technol., 2016, vol. 4, p. 52. https://doi.org/10.1002/ente.201500349

49. Peral, E. and Martín, M., Ind. Eng. Chem. Res., 2015, vol. 54, p. 7465. https://doi.org/10.1021/acs.iecr.5b00823

50. Khadzhiev, S.N., Kolesnichenko, N.V., Lin, G.I., Markova, N.A., Bukina, Z.M., Ionin, D.A., and Grafova, G.M., RF Patent 2442767, 2012.

51. Magomedova, M.V., Galanova, E.G., Afokin, M.I., Kipnis, M.A., Matieva, Z.M., and Maksimov, A.L., J. Nat. Gas. Sci. Eng., 2020, vol. 78, p. 103288. https://doi.org/10.1016/j.jngse.2020.103288

52. Haldor Topsoe, A.S., EUR 11808 Selective Hydrocarbon Synthesis. Demonstration Project, 1988, p. 23.

53. Mysov, V.M., Stepanov, V.G., and Ione, K.G., RF Patent 2339603, 2008. 